\title{
ROLA PRZYWÓDZTWA TRANSFORMACYJNEGO I TRANSAKCYJNEGO W KSZTALTOWANIU EFEKTYWNOŚCI URZĘDÓW GMINY
}

DOI: $10.33141 /$ po. 2020.11.02

\author{
Izabela Marzec
}

\section{Wprowadzenie}

0 d lat 90. XX wieku wraz ze zmianami zachodzącymi w sektorze publicznym i rozwojem nowych koncepcji zarządzania publicznego poprawa efektywności funkcjonowania stała się jednym z kluczowych celów administracji publicznej w wielu krajach (Lin, Tan, 2014, s. 97). Jej efektywność stanowi bowiem ważny czynnik oddziałujący na rozwój społeczno-gospodarczy kraju (Frączkiewicz-Wronka, 2010, s. 41-60). Dynamiczne otoczenie i wysokie oczekiwania społeczne co do efektywności działania jednostek administracji samorządowej stanowią dzisiaj poważne wyzwanie dla ich kadry zarząadzającej. W tym kontekście należy zwrócić uwagę na oddziaływanie przywództwa na efektywność funkcjonowania administracji samorządowej. Nieadekwatne przywództwo może prowadzić do narastania sytuacji problemowych, negatywnie oddziałując na realizację celów i zadań jednostek administracji samorządowej (Kellis, Ran, 2013, s. 132). Nowe koncepcje zarządzania publicznego eksponują znaczenie przywództwa jako istotnego czynnika wpływającego na efektywność funkcjonowania administracji publicznej. Ich zwolennicy sugerują nawet, że od dostosowanego do kontekstu sytuacyjnego typu przywództwa w dużej mierze zależy skuteczność działania administracji publicznej (Denhardt, Denhardt, 2000, s. 554). W związku $\mathrm{z}$ tym podejmowane są liczne próby adaptowania teorii przywództwa, które rozwinęly się na gruncie zarządzania w organizacjach prywatnych do potrzeb zarządzania publicznego. Wysiłki te mają tym większe znaczenie, że specyfika i cele administracji publicznej sprawiają, że jej efektywność stanowi kombinację wyników społecznych i finansowych. Konieczność dalszych przemian w administracji samorządowej powoduje, że w ostatniej dekadzie szczególne zainteresowanie badaczy budzi koncepcja przywództwa transformacyjnego i transakcyjnego oraz wpływu, jaki przywódcy wywierają na sposób definiowania celów organizacji, ich realizację i efektywność funkcjonowania organizacji (Pasha i in., 2017, s. 723). Pomimo jednak faktu, że niewątpliwie przywództwo pełni ważną rolę w kształtowaniu efektywności organizacji, nadal stosunkowo rzadko jest przedmiotem badań empirycznych prowadzonych $\mathrm{w}$ polskiej administracji samorządowej. Ważnym zadaniem dla teoretyków i praktyków zarządzania publicznego staje się zatem określenie relacji między przywództwem a efektywnością funkcjonowania jednostek administracji samorządowej.
Przegląd Organizacji, Nr 11(970), 2020, s. 11-17

www.przegladorganizacji.pl

๑ Towarzystwo Naukowe Organizacji i Kierownictwa (TNOiK)
Celem artykułu jest próba odpowiedzi na pytanie: jakie związki występują pomiędzy przywództwem transformacyjnym i transakcyjnym a efektywnością funkcjonowania jednostek administracji samorządowej? Cel ten zostanie zrealizowany poprzez przedstawienie wyników studiów literatury i badań ankietowych zrealizowanych w urzędach gminy Górnośląsko-Zagłębiowskiej Metropolii (GZM).

\section{Przywództwo transakcyjne i transformacyjne: zarys zakresu pojęciowego}

$\mathbf{P}$ rzywództwo jest złożonym fenomenem od dawna fascynującym badaczy $\mathrm{z}$ różnych dziedzin. Istnieje wiele różnorodnych teorii i koncepcji przywództwa, lecz ich wspólną cechą jest uwypuklenie znaczenia wpływu wywieranego przez przywódcę na członków organizacji $\mathrm{i}$ jej funkcjonowanie. Jedną $\mathrm{z}$ nich jest koncepcja przywództwa transakcyjnego i transformacyjnego. Według M.J. Burnsa (1978, s. 169-369) - prekursora teorii przywództwa transformacyjnego, można wyróżnić dwa typy przywódców, tj. transakcyjnych i transformacyjnych. Teoria ta, chociaż powstała na gruncie politologii, również w zarządzaniu zyskała dużą popularność. Rozwinięta została przez B. Bassa (1985), który twierdził, że w organizacji można wyróżnić liderów przejawiających zachowania transakcyjne, transformacyjne i leseferyczne.

Przywództwo transakcyjne opiera się na relacji wymiany zachodzącej pomiędzy przywódcą a członkami grupy - w zamian za realizację oczekiwań przywódcy podwładni otrzymują nagrody zaspokajające ich różnorodne, głównie jednak podstawowe potrzeby, takie jak np. potrzebę bezpieczeństwa, przynależności czy uznania. Przywódca transakcyjny zachęca podwładnych do realizacji wyznaczonych zadań i nagradza ich za pożądane zachowania, a interweniuje, gdy ich zachowania odbiegają od oczekiwanych przez niego standardów (Gigol, 2016, s. 250). Do podstawowych cech przywództwa transakcyjnego należy uwarunkowanie nagród wynikami pracowników oraz monitorowanie i korygowanie ich działań $\mathrm{w}$ razie zaistnienia takiej potrzeby (Kellis, Ran, 2013). Przywódca transakcyjny koncentruje się na kontroli realizacji założonych celów oraz korygowaniu działań w razie wystąpienia błędów i odchyleń w realizacji ustalonych planów. Warto zauważyć, że przywództwo transakcyjne może przybierać 
zarówno pozytywne, jak i negatywne formy. W formie pasywnej, która może być traktowana jako odpowiednik przywództwa leseferycznego, w którym lider unika zaangażowania i podejmuje, często spóźnione, działania dopiero, gdy pojawią się sytuacje problemowe. Przywództwo transakcyjne określane jest również jako przywództwo menedżerskie, ponieważ skupia się ono na realizacji typowych funkcji i zadań menedżerskich, takich jak planowanie, organizowanie, kontrola itp. (Bass, 1985).

W odróżnieniu od przywództwa transakcyjnego przywództwo transformacyjne motywuje pracowników do przekraczania przez nich formalnego zakresu obowiązków, wynikającego z umowy zatrudnienia - lider skutecznie zachęca pracowników do dodatkowego wysiłku na rzecz organizacji. Pobudza ich zachowania obywatelskie. Przywódcy transformacyjni wpływają pozytywnie na samoocenę pracowników poprzez wzmacnianie ich poczucia kompetencji (Shamir i in., 1993, s. 581-583). Tacy przywódcy potrafią przekonać pracowników, że ich praca jest ważna - nadają ich działaniom głębszy sens, dzięki czemu pracownicy silniej angażują się w wykonywane zadania, odczuwają większą satysfakcję z pracy i osiągają lepsze wyniki pracy (Van der Heijden, Bakker, 2011, s. 235). Do cech charakterystycznych przywództwa transformacyjnego należą np. (Gigol, 2016, s. 250):

- wyidealizowany wpływ (charyzma) - lider jest dla innych wzorem, osobą szanowaną i podziwianą, posiadającą wizję organizacji, której realizacja jest dla niego ważniejsza niż osobiste potrzeby, cele i interesy;

- inspirująca motywacja - przywódca motywuje i inspiruje pracowników przez stawianie im ambitnych, będących dla nich wyzwaniem, zadań. Jego wizja przyszłości organizacji jest atrakcyjna dla pracowników;

- stymulacja intelektualna - przywódca transformacyjny pobudza kreatywność i inicjatywę pracowników, zachęca ich do kwestionowania przyjętych sposobów działania i poszukiwania nowych rozwiązań;

- indywidualne podejście - przywódca uwzględnia indywidualne potrzeby pracowników, wspiera ich dążenie do samorealizacji, często jest także ich mentorem.

Przegląd literatury sugeruje, że zarówno przywódcy transakcyjni, jak i transformacyjni kształtują kontekst społeczny funkcjonowania organizacji, silnie wpływając na postawy i zachowania pracowników. Gwałtowne przemiany w otoczeniu sprawiały, że w ostatniej dekadzie w literaturze przedmiotu szczególnie silnie eksponowane jest znaczenie przywództwa transformacyjnego i jego rola w kreowaniu zmian organizacyjnych. Należy jednak zauważyć, że to przywódcy transakcyjni w „codziennej praktyce działania” określają warunki procesu wymiany zachodzącej pomiędzy pracownikami a organizacją, legitymizując pożądane wzorce zachowań, oddziałując tym samym na wyniki ich pracy. Te dwa odmienne typy przywództwa nie są zatem wobec siebie konkurencyjne czy przeciwstawne, lecz wzajemnie się dopełniają, stanowiąc ważny czynnik sukcesu organizacji w dynamicznym i nieprzewidywalnym otoczeniu.

\section{Efektywność funkcjonowania administracji publicznej}

E fektywność jest pojęciem różnie definiowanym, które może być ujmowane z wielu perspektyw. Mimo że problematyka efektywności, jej pomiaru i uwarunkowań w odniesieniu do organizacji biznesowych cieszy się nieustannym zainteresowaniem praktyków i teoretyków zarządzania od lat siedemdziesiątych XX wieku, to jednak prace badawcze dotyczące efektywności organizacji publicznych są zdecydowanie mniej liczne (Głodziński, 2015; Bratnicki, Kulikowska-Pawlak, 2013).

Studia literatury wskazują, że w analizie efektywności jednostek administracji samorządowej dominują obecnie dwa podejścia szczególnie odpowiadające specyfice ich funkcjonowania, tj. podejście od strony interesariuszy oraz podejście oparte na modelu konkurujących wartości (Kulikowska-Pawlak, 2010). Według podejścia od strony interesariuszy, podstawowym kryterium oceny efektywności jest stopień, w jakim organizacja spełnia oczekiwania swoich interesariuszy (Love, Skitmore, 1996, s. 6). Z kolei, zgodnie z założeniami podejścia opartego na modelu konkurujących wartości, efektywność jest pojęciem wielowymiarowym i nie można jednoznacznie wskazać jej najlepszych kryteriów oceny, bowiem zależą one od określonej sytuacji decyzyjnej (Marzec, Ganiek, 2018, s. 378-380). Należy zauważyć, że problem pomiaru efektywności w administracji samorządowej ma złożony charakter ze względu na specyfikę jej funkcjonowania, misji i celów, stąd też istnieje konieczność jej wielowymiarowej oceny.

Chociaż poprawa efektywności funkcjonowania jednostek administracji samorządowej nie jest możliwa bez jej wiarygodnych miar, stosowanie kryteriów ekonomicznych, dominujących w sektorze prywatnym, ma dużo mniejsze zastosowanie niż w sektorze prywatnym (Frączkiewicz-Wronka, 2010, s. 41-60). Niewątpliwie w przypadku oceny efektywności administracji samorządowej szczególnie ważny jest jej wymiar społeczny. Wyniki działania jednostek administracji samorządowej w dużej mierze mają charakter niematerialny. Ważnym kryterium oceny efektywności administracji samorządowej jest także społeczna legitymizacja działania, świadcząca o umiejętności zarządzania relacjami $\mathrm{z}$ interesariuszami (Wronka, 2014, s. 377; Marzec, Ganiek, 2018 , s. 380). Ocena ta opiera się na podejściu od strony wielokrotnych wyborów, zgodnie z którą organizacja nie może istnieć bez wsparcia jej kluczowych interesariuszy, tj. w przypadku gminy - jej mieszkańców. W rezultacie stopień, w jakim gmina spełnia ich oczekiwania, stanowi jedno $\mathrm{z}$ podstawowych kryteriów oceny efektywności funkcjonowania jej jednostek (Bratnicki, Kulikowska-Pawlak, 2013, s. 58). Społeczna legitymizacja działania z kolei w dużej mierze zależy od realizacji przez administrację samorządową jej misji, którą stanowi „rzetelne, skuteczne i zgodne z prawem wykonywanie polityki publicznej" (Sześciło i in., 2014, s. 46), co na poziomie gminy oznacza zapewnianie wysokiej jakości usług publicznych jej mieszkańcom. Realizacja misji może być 
zatem uznawana za jedno $\mathrm{z}$ ważnych kryteriów oceny efektywności. Nawiązuje ono do podejścia celowościowego, zgodnie z którym efektywność jest oceniana poprzez stopień realizacji przez organizację jej celów. Należy także zauważyć, że realizacja celów gminy istotnie zależy od posiadanych zasobów finansowych. Gmina korzysta $\mathrm{z}$ różnych źródeł dochodów. Oszczędność i gospodarność wpływają na stabilność finansową gminy i jej jednostek - dlatego stabilność finansowa także stanowi ważną miarę efektywności w odniesieniu do organizacji publicznych (Wronka, 2014, s. 375; Marzec, Ganiek, 2018, s. 380).

Zmiany zachodzące w zarządzaniu publicznym sprawiły, że poprawa efektywności funkcjonowania administracji samorządowej jest dzisiaj postrzegana jako jeden z podstawowych warunków dalszych przeobrażeń sektora publicznego. Zdaniem badaczy, sukces organizacji publicznych silnie zależy od skutecznego przywództwa, które skupia się na realizacji procesów zarządczych, a nie celów politycznych (Austen, 2010, s. 28). Przemiany $\mathrm{w}$ administracji samorządowej powodują, że szczególna rola przypisywana jest przywódcom transformacyjnym, którzy posiadają zdolność identyfikowania nowych wyzwań w dynamicznym otoczeniu i tworzenia strategii będących na nie stosowną odpowiedzią (Ljungholm, 2014, s. 111-112). Potrafią oni zmotywować pracowników do dodatkowego wysiłku na rzecz organizacji. Badania empiryczne przeprowadzone $\mathrm{w}$ polskich organizacjach publicznych, które obejmowały między innymi urzędy gminy, wykazały, że przywództwo transformacyjne wpływa dodatnio na jakość działania pracowników i ich wysiłek wkładany w pracę (Strużyna, Marzec, 2017, s. 39-54). Można zatem przypuszczać, że przywództwo transformacyjne oddziałuje również pozytywnie na efektywność funkcjonowania organizacji. Należy jednak zauważyć, że przywództwo transformacyjne nie może $\mathrm{w}$ administracji publicznej zastąpić przywództwa transakcyjnego. Są one względem siebie komplementarne, bowiem zwłaszcza w przypadku administracji samorządowej ważna jest również pewna stabilność i ciągłość $\mathrm{w}$ realizacji ustalonych celów polityki publicznej. Badania przeprowadzone w sektorze publicznym w Stanach Zjednoczonych wykazały, że liderzy transformacyjni pozytywnie wpływają na postrzeganie wartości misji organizacji wśród pracowników, klarowność celów oraz zarządzanie efektywnością (Pasha i in., 2017, s. 731-735). W kontekście zmian zachodzących w administracji samorządowej istnieją przesłanki, aby przypuszczać, że liderzy zachęcający pracowników do podejmowania inicjatywy, dodatkowego wysiłku na rzecz organizacji oraz poszukiwania nowych wyzwań i możliwości rozwoju mogą silniej dodatnio oddziaływać na efektywność funkcjonowania organizacji niż przywódcy transakcyjni. Studia literatury doprowadziły zatem do postawienia następujących hipotez badawczych:

H1: Istnieje dodatni związek pomiędzy przywództwem transakcyjnym a efektywnością funkcjonowania urzędów gminy.

H2: Istnieje dodatni związek pomiędzy przywództwem transformacyjnym a efektywnością funkcjonowania urzędów gmin.

H3: Związek między efektywnością funkcjonowania urzędów gminy a przywództwem transformacyjnym jest silniejszy niż pomiędzy efektywnością funkcjonowania urzędów gminy a przywództwem transakcyjnym.

\section{Metoda badawcza}

B adania terenowe zostały zrealizowane w 2019 roku wśród 153 pracowników zatrudnionych w urzędach gmin wchodzących w skład Górnośląsko-Zagłębiowskiej Metropolii (GZM)․ W każdym urzędzie gminy w badaniu wzięło udział od 3 do 5 pracowników. Liczba ankietowanych pracowników urzędu była zależna od liczby mieszkańców gminy, z czego: 66 badanych była zatrudniona w gminach do 20000 mieszkańców,

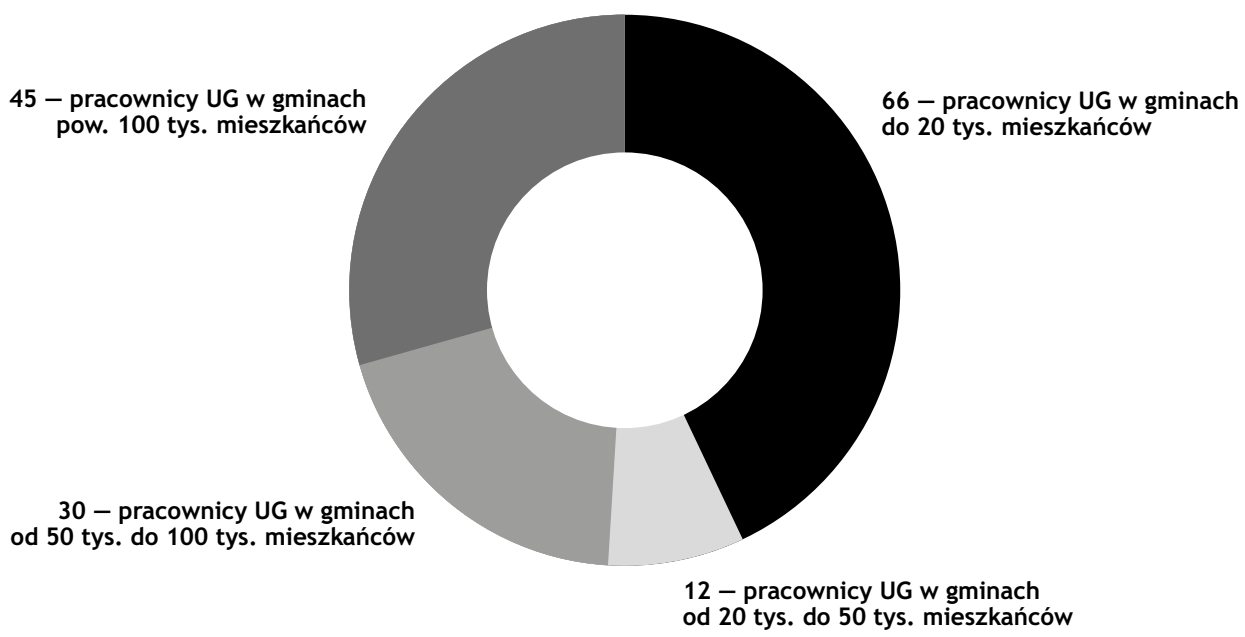

Rys. 1. Liczebność badanych grup pracowników urzędów gminy przy zastosowaniu kryterium liczby mieszkańców gminy

Źródto: opracowanie własne 
12 badanych w gminach od 20001 do 50000 mieszkańców, 30 w gminach od 50001 do 100000 mieszkańców, a 45 ankietowanych w gminach powyżej 100000 mieszkańców (rys. 1). Badania objęły wszystkie urzędy gminy GZM (41 urzędów).

Ze względu na specyfikę zatrudnienia w urzędach gminy w badaniu wzięło udział 31 mężczyzn i 122 kobiety. Średni wiek badanych wynosił 41,3 lat (odchylenie standardowe 8,8 lat). Na skutek wymogów kompetencyjnych stawianych pracownikom administracji publicznej zdecydowana większość badanych posiadała wykształcenie wyższe magisterskie $(81,7 \%)$, tylko $11,8 \%$ respondentów posiadało wykształcenie wyższe licencjackie i 6,5\% wykształcenie średnie policealne.

Do pomiaru efektywności funkcjonowania urzędów gminy zastosowano skalę opracowaną przez M. Wronkę (2014, s. 363-387), w której budowie wykorzystano wcześniej skonstruowane skale D. Snowa (1992, s. 213-214) i C. Cornfortha (2001, s. 217-227). Skala ta opiera się na subiektywnej ocenie efektywności funkcjonowania organizacji publicznych pod względem trzech wymiarów, tj. stabilności finansowej, realizacji misji i społecznej legitymizacji działania. Do pomiaru typu przywództwa wykorzystano zmodyfikowane narzędzie D.N. Hartoga, J.J. Van Muijena i P.L. Koopman (1997, s. 19-34) oraz B.J. Avolio, B.M. Bassa i D.I. Junga (1999, s. 441-462), obejmujące skale do pomiaru przywództwa transformacyjnego i transakcyjnego. We wszystkich odpowiedziach zastosowano 7-stopiniową skalę Likera (1 - zdecydowanie nie zgadzam się, 7 - zdecydowanie zgadzam się z danym stwierdzeniem). W analizie statystycznej uzyskanych danych empirycznych wykorzystano program SPSS 24.0.

Aby przetestować postawione hipotezy, w pierwszej kolejności obliczono statystyki opisowe badanych zmiennych (tab. 1 i 2). Typ przywództwa i efektywność funkcjonowania organizacji mierzono za pomocą średnich ocen pozycji danej skali. Uzyskany wynik stanowi ich syntetyczną oceną. Jej obliczanie jest uprawomocnione przy założeniu, że dane mierzone w skalach Likerta przy konstruowaniu syntetycznych wskaźników mogą być traktowane jako dane ciągłe o charakterze przedziałowym, co jest powszechnie stosowane $\mathrm{w}$ badaniach $\mathrm{z}$ zakresu zarządzania (Wieczorkowska i in., 2003, s. 40; Nawojczyk, 2002, s. 54-57).

\section{Wyniki badań}

A naliza typu przywództwa wykazała, że zarówno przywództwo transakcyjne, jak i transformacyjne zostało wysoko ocenione przez badanych pracowników urzędów gminy. Przy czym nieco wyższe oceny uzyskało przywództwo transformacyjne (średnia - 5,25 punktu w skali siedmiostopniowej; przywództwo transakcyjne - średnia 5,15 punktu). Należy zauważyć, że oceny przywództwa transakcyjnego i transformacyjnego cechowały się stosunkowo dużym zróżnicowaniem - odchylenie standardowe przekroczyło 1 punkt w skali siedmiopunktowej (tab. 1).

W odniesieniu do efektywności funkcjonowania urzędów gminy również jej poziom został wysoko oceniony przez badanych - średnia wyniosła 5,26 punktu w skali siedmiostopniowej. Jednak oceny poziomu jej poszczególnych wymiarów wyraźnie się różniły. Najwyżej oceniono społeczną legitymizację działania urzędów gminy (średnia - 5,63 punktu w skali siedmiostopniowej). Niższe oceny uzyskał wymiar „realizacja misji" (średnia - 5,33 punktu w skali siedmiostopniowej). Najniżej badani pracownicy ocenili stabilność finansową urzędów gminy (średnia - 4,79 punktu w skali siedmiostopniowej) (tab. 2).

W następnej kolejności przeprowadzono analizę korelacji Pearsona (przy założeniach, że badane zmienne

Tabela 1. Zestawienie statystyk opisowych oceny przywództwa transformacyjnego i transakcyjnego w urzędach gminy

\begin{tabular}{|c|c|c|c|c|}
\hline Zmienne & Minimum & Maksimum & Średnia & Odchyl. stand. \\
\hline Przywództwo transakcyjne & 1,00 & 7,00 & 5,15 & 1,15 \\
\hline Przywództwo transformacyjne & 1,56 & 7,00 & 5,25 & 1,14 \\
\hline
\end{tabular}

Źródto: opracowanie wtasne

Tabela 2. Zestawienie statystyk opisowych dotyczących efektywności funkcjonowania urzędów gminy

\begin{tabular}{|c|c|c|c|c|}
\hline Zmienne & Minimum & Maksimum & Średnia & Odchyl. stand. \\
\hline Stabilność finansowa & 1,00 & 7,00 & 4,79 & 1,19 \\
\hline Realizacja misji & 1,75 & 7,00 & 5,33 & 1,02 \\
\hline Społeczna legitymizacja & 2,00 & 7,00 & 5,63 & 0,87 \\
\hline Efektywność - ocena ogólna & 2,70 & 7,00 & 5,26 & 0,87 \\
\hline
\end{tabular}

Źródto: opracowanie wtasne 
stanowią syntetyczne wskaźniki, które, jak wspomniano, mogą być traktowane jako zmienne o charakterze interwałowym) (tab. 3). Wykazała ona, że efektywność funkcjonowania urzędów gminy jest wyraźnie, dodatnio skorelowana zarówno $\mathrm{z}$ przywództwem transakcyjnym $(\mathrm{r}=0,507, \mathrm{p}<0,01)$, jak i transformacyjnym $(\mathrm{r}=0,525$, $\mathrm{p}<0,01)$, co jednocześnie potwierdza przedstawione hipotezy H1 i H2. Stwierdzono jednocześnie, że przywództwo transformacyjne jest nieco silniej powiązane $\mathrm{z}$ efektywnością funkcjonowania urzędów gminy. Warto zauważyć, że najsilniej powiązanym $\mathrm{z}$ przywództwem transakcyjnym i transformacyjnym wymiarem efektywności była realizacja misji organizacji $(\mathrm{r}=0,517, \mathrm{p}<0,01 \mathrm{w}$ obu przypadkach). Wyraźnie słabsze korelacje między przywództwem transakcyjnym i transformacyjnym a badanymi wymiarami efektywności funkcjonowania wystąpiły w odniesieniu do społecznej legitymizacji działania (wynosiły one odpowiednio: $r=0,391$ i $r=0,375, p<0,01)$. Na uwagę zasługuje również fakt, że w przypadku stabilności finansowej silniej niż przywództwo transakcyjne $(\mathrm{r}=0,36, \mathrm{p}<0,01)$ powiązanym $\mathrm{z}$ tym wymiarem efektywności było przywództwo transformacyjne $(\mathrm{r}=0,417, \mathrm{p}<0,01)$.

$\mathrm{W}$ celu sprawdzenia, czy różnice występujące $\mathrm{w}$ poziomie korelacji między ogólną oceną efektywności funkcjonowania a przywództwem transformacyjnym i transakcyjnym są statystycznie istotne, wykorzystano test t Williamsa dla dwóch korelacji prób zależnych, obliczony według wzorów (Chen, Popovich, 2002, s. 24):

(1) $t=\left(r_{j k}-r_{j h}\right) \sqrt{\frac{(n-1)\left(1+r_{k h}\right)}{2[(n-1) /(n-3)]|R|+\bar{r}^{2}\left(1-r_{k h}\right)^{3}}}$

gdzie: (2) $|R|=1-r_{j k}^{2}-r_{j h}^{2}-r_{k h}^{2}-2 r_{j k} r_{j h} r_{k h}$ $\operatorname{oraz}(3) \bar{r}=\left(r_{j k}+r_{j h}\right) / 2$

Uzyskane wyniki analizy przedstawia tabela 4. Analiza wykazała, że obliczona wartość testu $t(t=0,449)$ nie należy do obszaru krytycznego i nie istnieją powody, aby odrzucić hipotezę H0 (tab. 4).

Podsumowując zatem uzyskane wyniki świadczą, że występująca różnica w poziomie korelacji nie jest istotna statystycznie, co jednocześnie pozwala na odrzucenie ostatniej z przedstawionych hipotez (H3).

\section{Podsumowanie}

D rzeprowadzona analiza statystyczna uzyskanych danych empirycznych pozwoliła na potwierdzenie postawionych hipotez $\mathrm{H} 1 \mathrm{i} \mathrm{H} 2$. Stwierdzono, że

Tabela 3. Analiza korelacji między przywództwem transformacyjnym i transakcyjnym a efektywnością funkcjonowania urzędu gminy

\begin{tabular}{|c|l|c|c|c|c|c|c|}
\hline Lp. & \multicolumn{1}{|c|}{ Zmienne } & $\mathbf{1 .}$ & $\mathbf{2 .}$ & $\mathbf{3 .}$ & $\mathbf{4 .}$ & $\mathbf{5 .}$ & $\mathbf{6 .}$ \\
\hline 1 & Przywództwo transformacyjne & - & & & & \\
\hline 2 & Przywództwo transakcyjne & $0,830^{* *}$ & - & & & & \\
\hline 3 & Stabilność finansowa & $0,417^{* *}$ & $0,360^{* *}$ & - & & & \\
\hline 4 & Realizacja misji & $0,517^{* *}$ & $0,517^{* *}$ & $0,587^{* *}$ & - & & \\
\hline 5 & Społeczna legitymizacja & $0,375^{* *}$ & $0,391^{\star *}$ & $0,420^{* *}$ & $0,694^{* *}$ & - & \\
\hline 6 & Efektywność - ocena ogólna & $0,525^{* *}$ & $0,507^{* *}$ & $0,810^{* *}$ & $0,917^{* *}$ & $0,797^{* *}$ & - \\
\hline
\end{tabular}

${ }^{*} \mathrm{p}<0,05 ;{ }^{* *} \mathrm{p}<0,01$

Źródło: opracowanie wtasne

Tabela 4. Analiza istotności różnic w poziomie korelacji między przywództwem transformacyjnym i transakcyjnym a efektywnością funkcjonowania urzędów gminy

\begin{tabular}{|c|c|c|}
\hline Hipotezy & Wartości korelacji & Statystyki \\
\hline$H 0: r_{j k}=r_{j h}$ & $r_{j k}=0,525$ & $n=153$ \\
\hline \multirow{2}{*}{$H 1: r_{j \mathbf{k}} \neq r_{\text {jh }}$} & $r_{j h}=0,507$ & obszar krytyczny $=1,976$ \\
\cline { 2 - 3 } & $r_{k h}=0,83$ & $|R|=0,2202$ \\
\cline { 2 - 3 } & & $t=0,449$ \\
\hline
\end{tabular}

$r_{j k}$ - wartość wspótczynnika korelacji między przywództwem transformacyjnym a efektywnością

$r_{j h}$ - wartość wspótczynnika korelacji między przywództwem transakcyjnym a efektywnością

$r_{k h}$ - wartość współczynnika korelacji między przywództwem transformacyjnym a transakcyjnym

Źródto: opracowanie wtasne 
występują dodatnie, istotne statystycznie związki pomiędzy przywództwem transakcyjnym i transformacyjnym a efektywnością funkcjonowania urzędów gminy. Ponadto zaobserwowany związek między efektywnością funkcjonowania urzędów gminy a przywództwem transformacyjnym był nieco silniejszy niż pomiędzy efektywnością funkcjonowania urzędów gminy a przywództwem transakcyjnym. Dalsza analiza wykazała jednak, że różnica występująca w poziomie korelacji między badanymi typami przywództwa a efektywnością jest nieistotna statystycznie, co jednocześnie doprowadziło do sfalsyfikowania hipotezy H3 mówiącej, iż związek między efektywnością funkcjonowania urzędów gminy a przywództwem transformacyjnym jest silniejszy niż pomiędzy efektywnością funkcjonowania urzędów gminy a przywództwem transakcyjnym. Uzyskane wyniki sugerują, że przywództwa transakcyjne i transformacyjne są powiązane $z$ efektywnością funkcjonowania urzędów gminy na zbliżonym poziomie, co równocześnie wskazuje, że w dynamicznym otoczeniu oba typy przywództwa są konieczne dla ich właściwego funkcjonowania. Na uwagę zasługuje jednakże fakt, że różnica występująca $\mathrm{w}$ poziomie korelacji przywództwem transformacyjnym i transakcyjnym a efektywnością była wyraźna w przypadku wymiaru stabilności finansowej. Fakt ten może świadczyć o tym, że w opinii badanych pracowników przywództwo transformacyjne bardziej sprzyja utrzymaniu stabilności finansowej urzędów gminy niż przywództwo transakcyjne. Należy jednocześnie wspomnieć, że to właśnie wymiar stabilności finansowej został najniżej oceniony przez badanych. W dalszych badaniach warto zidentyfikować przyczyny tego zjawiska. Umiejętność zarządzania zasobami finansowymi urzędu gminy, racjonalne i oszczędne gospodarowanie nimi są ważnymi czynnikami decydującymi o powodzeniu podejmowanych w gminie działań. Stąd też należy określić czynniki powodujące wyraźnie niższą ocenę stabilności finansowej badanych urzędów gminy. Ich dalsza diagnoza może istotnie przyczynić się do poprawy efektywności funkcjonowania urzędów gminy.

Warto także zauważyć, że wartość uzyskanych wyników w dużej mierze wynika $\mathrm{z}$ faktu, że przedmiot badań jest związany z administracją samorządową, której specyfika jest wyraźnie akcentowana w literaturze przedmiotu (Boyne, 2002, s. 97-122). W kontekście niedostatku wiedzy o czynnikach warunkujących efektywność funkcjonowania administracji samorządowej istotnym nie tylko poznawczo, lecz także praktycznie wyzwaniem dla zarządzania publicznego stała się analiza związków między typem przywództwa a efektywnością funkcjonowania urzędów gminy. Należy także wskazać na ograniczenia przedstawionych wyników, które jednocześnie wyznaczają kierunki przyszłych badań. W zaprezentowanej analizie uwzględnione zostały jedynie relacje pomiędzy przywództwem transformacyjnym i transakcyjnym a efektywnością funkcjonowania urzędów gminy. $\mathrm{W}$ przyszłych badaniach należy ustalić relacje występujące między innymi czynnikami organizacyjnymi i indywidualnymi a efektywnością urzędów gminy, jak również związki między typem przywództwa a potencjalnymi czynnikami indywidualnymi, takimi jak, np.: zaangażowanie pracowników, poziom ich motywacji, satysfakcji z pracy a efektywnością funkcjonowania urzędów gminy. Podsumowując, można stwierdzić, że przedstawione wyniki wyraźnie wskazują, że rozpoznanie relacji między przywództwem a efektywnością organizacji dostarcza wartościowych wskazówek dla kadry zarządzającej jednostek administracji samorządowej. Pozwala na świadome kształtowanie zachowań przywódców w różnorodnych sytuacjach decyzyjnych, oddziałując korzystnie na efektywność organizacji. Świadczy, że w jednostkach administracji samorządowej dla realizacji ich celów konieczne jest stosowanie zarówno przywództwa transformacyjnego, jak i transakcyjnego.

\section{dr hab. Izabela Marzec, prof. uczelni Uniwersytet Ekonomiczny w Katowicach Kolegium Ekonomii ORCID: 0000-0002-7149-7566 e-mail: izabela.marzec@ue.katowice.pl}

\section{Przypis}

1) Projekt badawczy pt. „Motywowanie pracowników jako element zarządzania zasobami ludzkimi w podmiotach świadczących usługi publiczne" realizowanego w Katedrze Zarządzania Publicznego i Nauk Społecznych Uniwersytetu Ekonomicznego w Katowicach pod kierownictwem prof. zw. dr hab. A. Frączkiewicz-Wronki.

\section{Bibliografia}

[1] Austen A. (2010), Efektywność przywództwa w organizacji publicznej, „Organizacja i Zarządzanie”, Vol. 4, Nr 12, s. $25-41$.

[2] Avolio B.J., Bass B.M., Jung D.I. (1999), Re-examining the Components of Transformational and Transactional Leadership Using the Multifactor Leadership Questionnaire, "Journal of Occupational and Organizational Psychology”, Vol. 72, No. 4, pp. 441-462.

[3] Bass B. (1985), Leadership and Performance beyond Expectations, Free Press, New York.

[4] Boyne G.A. (2002), Public and Private Management: What's the Difference? „Journal of Management Studies”, Vol. 39, No. 1, pp. 97-122.

[5] Bratnicki M., Kulikowska-Pawlak M. (2013), Uwarunkowania pomiaru efektywności organizacji, „Zarządzanie i Finanse", Vol. 4, Nr 2, s. 53-66.

[6] Burns M.J. (1978), Leadership, Harper and Collins, New York.

[7] Chen P.Y., Popovich P.M. (2002), Correlation: Parametric and Nonparametric Measures, Sage Publications, Thousand Oaks. 
[8] Cornforth C. (2001), What Makes Boards Effective? An Examination of the Relationships between Board Inputs, Structures, Processes and Effectiveness in Non-profit Organizations, „Corporate Governance”, Vol. 9, No. 3, pp. 217-227.

[9] Denhardt R.B., Denhardt J.V. (2000), The New Public Service: Serving Rather than Steering, „Public Administration Review", Vol. 60, No. 6, pp. 549-555.

[10] Frączkiewicz-Wronka A. (2010), Nowoczesna koncepcja świadczenia usług publicznych - zmiana $w$ kierunku nowego zarządzania publicznego, [w:] A. Frączkiewicz-Wronka (red.), Pomiar efektywności organizacji publicznych na przykładzie sektora ochrony zdrowia, Wyd. AE, Katowice, s. 19-62.

[11] Gigol T. (2016), Przywództwo w nowoczesnej administracji publicznej, „Zeszyty Naukowe PWSZ w Płocku”, t. XXIV, s. 247-256.

[12] Głodziński E. (2015), Efektywność w naukach o zarządzaniu. Przyczyny wieloznaczności i rekomendacje dotyczace ich ograniczenia, „Zeszyty Naukowe Politechniki Śląskiej, seria: Organizacja i Zarządzanie”, z. 83, s. 165-176.

[13] Hartog D.N., Van Muijen J.J., Koopman P.L. (1997), Transactional versus Transformational Leadership: An Analysis of the MLQ, "Journal of Occupational and Organizational Psychology", Vol. 70, No. 1, pp. 19-34.

[14] Kellis D., Ran B. (2013), Modern Leadership Principles for Public Administration: Time to Move Forward, ,Journal of Public Affairs", Vol. 13, No. 1, pp. 130-141.

[15] Kulikowska-Pawlak M. (2010), Pojmowanie efektywności organizacji - definiowanie, pomiar, [w:] A. Frączkiewicz-Wronka (red.), Pomiar efektywności organizacji publicznych na przykładzie sektora ochrony zdrowia, Wyd. AE, Katowice, s. 63-99.

[16] Lin Ch.L., Tan H.L. (2014), Performance Measurement in the Public Sector: Example of the Building Administration Authorities in Taiwan, „Journal of Management in Engineering", Vol. 30, No. 1, pp. 97-107.

[17] Ljungholm D.P. (2014), The Performance Effects of Transformational Leadership in Public Administration, "Contemporary Readings in Law and Social Justice”, Vol. 6, No. 1, pp. 110-115.

[18] Love P.E.D., Skitmore M.R. (1996), Approaches to Organisational Effectiveness and their Application to Construction Organisations, [in:] A. Thorpe (ed.), Proceedings 12th Annual Conference and Annual General Meeting, The Association of Researchers in Construction Management, Sheffield Hallam University, http://eprints.qut. edu.au/archive/00004524, access date: 05.08.2009.

[19] Marzec I., Ganiek A. (2018), Stosunek pracowników do zmian jako czynnik efektywności organizacji świadczacych usługi publiczne, „Społeczeństwo i Edukacja. Międzynarodowe Studia Humanistyczne", Vol. 29, Nr 2, s. 377-387.

[20] Nawojczyk M. (2002), Przewodnik po statystyce dla socjologów, SPSS Polska, Kraków.

[21] Pasha O., Poister T.H., Wright B.E., Thomas J.C. (2017), Transformational Leadership and Mission Valence of Employees: The Varying Effects by Organizational Level, „Public Performance \& Management Review”, Vol. 40, No. 4, pp. $722-740$.
[22] Shamir B., House R.J., Arthur M.J. (1993), The Motivational Effects of Charismatic Leadership: A Self-concept Based Theory, „Organization Science”, Vol. 4, No. 4, pp. 577-594.

[23] Snow D. (1992), Inside the Environmental Movement: Meeting the Leadership Challenge, Island Press, Washington.

[24] Strużyna J., Marzec I. (2017), Provided Leadership and Selected Outcomes of Trainings in Public Organizations, „Edukacja ekonomistów i menedżerów. Problemy. Innowacje. Projekty”, Vol. 46, Nr 4, s. 39-54.

[25] Sześciło D., Mendis A., Niziołek M., Jakubek-Lalik J. (2014), Administracja i zarządzanie publiczne. Nauka o współczesnej administracji, Stowarzyszenie Absolwentów Wydziału Prawa i Administracji Uniwersytetu Warszawskiego, Warszawa.

[26] Van der Heijden B., Bakker A. (2011), Toward a Mediation Model of Employability Enhancement: A Study of Employee-Supervisor Pairs in the Building Sector, „Career Development Quarterly”, Vol. 59, No. 3, pp. 232-248.

[27] Wieczorkowska G., Kochański P., Eljaszuk M. (2003), Statystyka. Wprowadzenie do analizy danych sondażowych i eksperymentalnych, Wyd. Naukowe Scholar, Warszawa.

[28] Wronka M. (2014), Sukces i jego pomiar w przedsiębiorstwach społecznych - próba operacjonalizacji, „Prace Naukowe Wałbrzyskiej Wyższej Szkoły Zarządzania i Przedsiębiorczości", Vol. 27, Nr 2, s. 363-387.

\section{The Role of Transformational and Transactional Leadership in Effectiveness of Municipal Offices}

\section{Summary}

Leadership and its impact on the effectiveness of organisational performance have raised interest of management researchers and practitioners for a long time. However, this issue is much less frequently discussed in relation to self-government administration. Analysis of the literature on the subject indicates that the effectiveness of performance of self-government administration units depends on the applied leadership type. This paper attempts to answer the question: what are the relationships between transformational and transactional leadership and the effectiveness of municipal offices' performance? This aim has been achieved by presenting the results of a literature study and survey research carried out in 41 municipal offices in Metropolis GZM. It has been found that both transformational and transactional leadership were positively connected to the effectiveness of municipal offices' performance and it has been revealed that the power of their relations with organisational effectiveness was at a similar level.

\section{Keywords}

leadership, organizational effectiveness, municipal offices 